\title{
Molecular Phylogenetics of Saw-scaled Viper (Echis carinatus) from Pakistan
}

\author{
Muhammad Rizwan Ashraf ${ }^{1}$, Asif Nadeem ${ }^{1,2}$, Eric Nelson Smith ${ }^{3}$, Maryam Javed ${ }^{1}$, \\ Utpal Smart $^{3}$, Tahir Yaqub ${ }^{4}$, Abu Saeed Hashmi ${ }^{1}$ and Panupong Thammachoti ${ }^{3}$ \\ ${ }^{1}$ Institute of Biochemistry and Biotechnology, University of Veterinary and Animal \\ Sciences, Lahore, Pakistan \\ ${ }^{2}$ Virtual University of Pakistan, Lahore \\ ${ }^{3}$ Amphibian and Reptile Diversity Research Center and Department of Biology, \\ University of Texas at Arlington, Arlington, TX 76019, USA \\ ${ }^{4}$ Department of Microbiology, University of Veterinary and Animal Sciences, Lahore
}
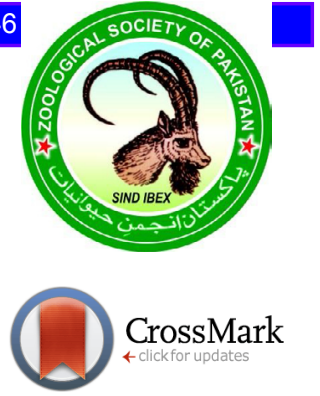

\section{A B S T R A C T}

Snakes are one of the most dangerous animals with over 40 species of venomous snakes found in Pakistan. One such group of snakes belongs to genus Echis is saw scaled viper (Ehcis carinatus). Molecular techniques have made it easy to elucidate phylogenetic relationships and evolutionary histories of different groups of organisms. This study is the first attempt to find the phylogenetic relationship and diversity through mitochondrial genes in saw-scaled viper from Pakistan. Tail tip biopsies of Sawscaled vipers were used for amplification of mitochondrial genes fragments (ND4, 16S rRNA and 12S rRNA) through Polymerase Chain Reaction (PCR). Nucleotide data was used for DNA polymorphism analyses and homology was measured among different species of genus Echis. Using the concatenated nucleotide data, Maximum likelihood and Bayesian phylogenetic trees were constructed that divided all Echis species into four groups. Saw-scaled viper in this study from Pakistan showed similarity and close relationship with Western India and UAE while showing difference from South Indian. Saw-scaled viper from South India is termed as Echis carinatus carinatus while that from Pakistan and Western India is Echis carinatus sochureki. More morphological and molecular studies are required to raise both the subspecies to separate species.

\section{INTRODUCTION}

$\mathrm{P}$ akistan reports 40,000 snake bites every year resulting in 8200 fatalities (Kasturiratne et al., 2008). Of the 40 venomous snakes of Pakistan, cobra, krait and vipers are common (Iliyas, 1997). Pakistan has three families of venomous land snake including Elapidae, viperdae and Crotalidae: Viperdae includes Echis carinatus sochureki, Echis carinatus astolae, E. c. multisquamatus, E. c. sochureki. Saw-scaled viper is a member of genus Echis and Family Viperidae. Many phylogenetic studies conducted in previous years divide Echis into 4 groups. Echis ocellatus, Echis pyramidum, Echis coloratus and Echis carinatus are the four groups of genus (Arnold et al., 2009). There are two subspecies of Echis carinatus i.e., Echis carinatus carinatus and Echis carinatus sochureki (Arnold, 1980; Arnold et al., 2009; Pook et al., 2009). The best source of phylogenetic information among vertebrates is thought to be mitochondrial DNA.

\footnotetext{
Corresponding author: asifnadeem@uvas.edu.pk 0030-9923/2020/0004-1517 \$ 9.00/0

Copyright 2020 Zoological Society of Pakistan
}

Many of the sequences are used completely while some partially are able to infer phylogenetic relationship among organisms (Macey et al., 2000). Mitochondrial genes have no introns which make it easier to amplify them and nuclear genes with introns should have been amplified in parts. Mitochondrial genes have high rate of substitutions but even then, they have some conserved regions that can be amplified through targeted PCR primers (Simon et al., 1994; Castresana, 2000).

Snakes have been the part of many phylogenetic studies for over a century, but higher-level relationships are still to be resolved. Many different phylogenies of snakes were generated a few decades ago. Morphological analysis (Lee and Scanlon, 2002a; Tchernov et al., 2020) showed a similar description of snake evolution but they have some opposite views about some particular taxa or regions of tree. Some molecular studies (Vidal and Hedges, 2002a; Vidal and Hedges, 2004; Lawson et al., 2004) have tried to resolve this issue by generating well supported clades. This study has been designed to infer biodiversity, variation and phylogenetic relationship of Saw-scaled viper from Pakistan. 


\section{MATERIALS AND METHODS}

The samples used in this study were tail tip biopsies $(n=25)$ of saw-scaled viper collected through reptile breeders from different cities of Pakistan. The samples were transferred to $70 \%$ ethanol before the DNA extraction. The sampling localities were plotted on the Pakistan map obtained from (https://www.ezilon.com/ maps/asia/pakistan-maps.html) as shown in the Figure 1. The sample IDs and coordinates of sampling sites are shown in the Tables I. DNA was extracted through standard organic method (Sambrook and Russel, 2001) and gently dissolved in $10 \mathrm{mM}$ Tris $(\mathrm{pH}=8.0)$ storing at $-20^{\circ} \mathrm{C}$ for further use. Polymerase Chain Reaction (PCR) primers used in previous studies were used for amplification of mitochondrial ND4 (Arevalo et al., 1994), 12S rRNA (Knight and Mindell, 1993), 16S rRNA (Vences et al., 2005) genes. Polymerase chain reactions used $0.01 \%$ bovine serum albumin and GoTaq ${ }^{\circledR}$ Flexi DNA polymerase master mix with Thermocycler Gene Amp ${ }^{\circledR} 9700$.

Amplified DNA was detected through 1.2\% agarose gel electrophoresis at $120 \mathrm{~V}$ for 35 minutes. After agarose gel electrophoresis, the PCR products were cleaned using absolute ethanol precipitation and sent for Sanger di-deoxy DNA sequencing.

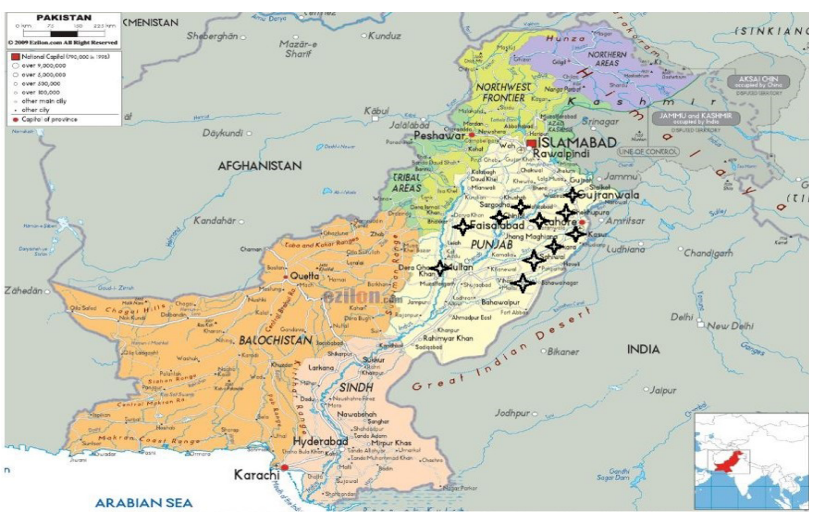

Fig. 1. Sample collection sites of Pakistan for saw-scaled viper (Echis carinatus).

\section{Data analyses}

Analyses of the sequence data were done through appropriate softwares. All the DNA sequences were uploaded on Sequencher v5.0 (Gene Codes, Ann Arbor, Michigan, USA). Contigs of each forward and reverse sequence chromatogram were made to get a consensus sequence making sure that there is no stop codon. Sequences with low quality than $70 \%$ were not used to avoid any ambiguity. The sequences were aligned through MEGA v6.0 (Tamura et al., 2013) software using Clustal
W (Larkin et al., 2007) multiple sequence alignment tool. The aligned nucleotide data was translated into amino acids using the vertebrate mitochondrial genetic code. DnaSP v. 5.0 (Librado and Rozas, 2009) was used for DNA polymorphism analyses. The polymorphism analyses included number of mutations, singleton variable sites, parsimony Informative sites, segregating sites, number of haplotypes, haplotype diversity, and nucleotide diversity. Using Multiple Sequence Comparison by LogExpectation (MUSCLE), homology was measured among different Echis species and presented in the form of line graph. All the contig sequences were concatenated through SequenceMatrix v1.7.8 software (Vaidya et al., 2011). PartitionFinder v1.10 (Lanfear et al., 2012) software gave best partitioning scheme and evolutionary models that were used in Bayesian Inference and Maximum Likelihood analyses.

\section{RESULTS}

Analysis of polymorphism in ND4, 16S rRNA and $12 \mathrm{~S}$ rRNA genes included number of mutations, singleton variable and parsimony informative sites along with haplotype and nucleotide diversity as shown in Table II. Using Multiple Sequence Comparison by LogExpectation (MUSCLE), homology was measured among different Echis species (Fig. 4). Maximum likelihood analyses were conducted using RaxML v8.00 (Stamatakis, 2014) on CIPRES Science Gateway server v3.2 (Miller et al., 2010). Nodal support was provided by bootstrapping (BS; 1,000 pseudo-replicates); with bootstrap values $\geq 70$ or 0.7 were considered as strong supports (Hillis and Bull, 1993). MrBayes v3.3 (Ronquist and Huelsenbeck, 2012) was used for Bayesian phylogenetic analyses. Two simultaneous runs of four Markov chain Monte Carlo (MCMC) analyses with total four chains (one cold plus three incrementally heated chains) were run with trees for $5 \times 310^{6}$ total generations (sampled every 500 generations). Burn-in value of $25 \%$ was set that discarded 2500 generations. Trace plots and ESS value $(>200)$ was used to examine stationarity on TRACER v1.5 (Rambaut and Drummind, 2009). Posterior probability (PP) values $\geq 0.95$ were considered as strong supports (Mulcahy et al., 2011). FigTree software (Rambaut, 2007) was used to visualize the resulting maximum likelihood (ML) and Bayesian inference (BI) phylogenies.

Maximum likelihood (ML) (Fig. 2) and Bayesian (BI) (Fig. 3) phylogenies were constructed using three mitochondrial genes. Cerastes cerastes (Egypt) was used as an out-group for all Echis that showed a well-supported sister group relationship to Genus Echis. Maximum likelihood and Bayesian phylogenies 
Table I. Saw-scaled Viper (Echis carinatus) samples and their location information.

\begin{tabular}{|c|c|c|c|}
\hline Samples ID & Locality & Latitude & Longitude \\
\hline EC-1 & Rehmat Pura, Okara, Punjab, Pakistan & $30^{\circ} 49^{\prime} 41.78^{\prime \prime} \mathrm{N}$ & $73^{\circ} 26^{\prime} 57.58^{\prime \prime} \mathrm{E}$ \\
\hline EC-2 & Chak 56/2 L Okara, Punjab, Pakistan & $30^{\circ} 49^{\prime} 36.05^{\prime \prime} \mathrm{N}$ & $73^{\circ} 29^{\prime} 26.05^{\prime \prime} \mathrm{E}$ \\
\hline EC-3 & Noor Garden, Okara, Punjab, Pakistan & $30^{\circ} 48^{\prime} 48.38^{\prime \prime} \mathrm{N}$ & $73^{\circ} 28^{\prime} 38.33^{\prime \prime} \mathrm{E}$ \\
\hline EC-4 & Tiba Maqsoodpura, Bahawalnagar, Punjab, Pakistan & $29^{\circ} 59^{\prime} 28.08^{\prime \prime} \mathrm{N}$ & $73^{\circ} 15^{\prime} 51.74 " \mathrm{E}$ \\
\hline EC-5 & Aziz Town, Bahawalnagar, Punjab, Pakistan & $29^{\circ} 58^{\prime} 39.26^{\prime \prime} \mathrm{N}$ & $73^{\circ} 15^{\prime} 6.63^{\prime \prime} \mathrm{E}$ \\
\hline EC-6 & Lahore Zoo, Lahore, Panjab, Pakistan & $31^{\circ} 33^{\prime} 23.78^{\prime \prime} \mathrm{N}$ & $74^{\circ} 19^{\prime} 33.73^{\prime \prime} \mathrm{E}$ \\
\hline EC-7 & Budla Sant, Multan, Punjab, Pakistan & $30^{\circ} 9^{\prime} 13.65^{\prime \prime} \mathrm{N}$ & $71^{\circ} 42^{\prime} 42.59^{\prime \prime} \mathrm{E}$ \\
\hline EC-8 & Model Town, Multan, Punjab, Pakistan & $30^{\circ} 14^{\prime} 39.35^{\prime \prime} \mathrm{N}$ & $71^{\circ} 29^{\prime} 58.88^{\prime \prime} \mathrm{E}$ \\
\hline EC-9 & Changa Manga Forest, Kasur, Punjab, Pakistan & $31^{\circ} 4^{\prime} 54.19^{\prime \prime} \mathrm{N}$ & $73^{\circ} 59^{\prime} 53.49^{\prime \prime} \mathrm{E}$ \\
\hline EC-10 & Lahore Zoo, Lahore, Panjab, Pakistan & $31^{\circ} 33^{\prime} 23.78^{\prime \prime} \mathrm{N}$ & 74ำ'33.73"E \\
\hline EC-11 & Jharianwala, Hafizabad, Punjab, Pakistan & $32^{\circ} 5 ' 26.11 " \mathrm{~N}$ & $73^{\circ} 40^{\prime} 29.85^{\prime \prime} \mathrm{E}$ \\
\hline EC-12 & Zafar Abad, Sheikhupura, Punjab, Pakistan & $31^{\circ} 41^{\prime} 13.28^{\prime \prime} \mathrm{N}$ & $74^{\circ} 3{ }^{\prime} 27.19^{\prime \prime} \mathrm{E}$ \\
\hline EC-13 & Dera Kalar wala, Sheikhupura, Punjab, Pakistan & $31^{\circ} 43^{\prime} 39.77^{\prime \prime} \mathrm{N}$ & $73^{\circ} 56^{\prime} 50.54 " \mathrm{E}$ \\
\hline EC-14 & Jharianwala, Hafizabad, Punjab, Pakistan & $32^{\circ} 5^{\prime} 26.11 " \mathrm{~N}$ & $73^{\circ} 40^{\prime} 29.85^{\prime \prime} \mathrm{E}$ \\
\hline EC-15 & Qadirabad, Sahiwal, Punjab, Pakistan & $30^{\circ} 43^{\prime} 22.36^{\prime \prime} \mathrm{N}$ & $73^{\circ} 14^{\prime} 59.99^{\prime \prime} \mathrm{E}$ \\
\hline EC-16 & Chak 225 RB Malkhanwala, Faisalabad, Punjab, Pakistan & $31^{\circ} 21^{\prime} 35.97 " \mathrm{~N}$ & $73^{\circ} 6^{\prime} 46.19 " \mathrm{E}$ \\
\hline EC-17 & Nawanpind, Faisalabad, Punjab, Pakistan & $31^{\circ} 15^{\prime} 7.49^{\prime \prime} \mathrm{N}$ & $73^{\circ} 3^{\prime} 13.71 " \mathrm{E}$ \\
\hline EC-18 & Dogranwala, Gujranwala, Punjab, Pakistan & $32^{\circ} 13^{\prime} 22.56^{\prime \prime} \mathrm{N}$ & $74^{\circ} 5^{\prime} 29.38^{\prime \prime} \mathrm{E}$ \\
\hline EC-19 & Hiran Minar Park, Sheikhupura, Punjab, Pakistan & $31^{\circ} 44^{\prime} 34.88^{\prime \prime} \mathrm{N}$ & $73^{\circ} 57^{\prime} 18.64 " \mathrm{E}$ \\
\hline EC-20 & Dera Kalar wala, Sheikhupura, Punjab, Pakistan & $31^{\circ} 43^{\prime} 39.77^{\prime \prime} \mathrm{N}$ & $73^{\circ} 56^{\prime} 50.54^{\prime \prime} \mathrm{E}$ \\
\hline EC-21 & Chak 7/4-L, Okara, Punjab, Pakistan & $30^{\circ} 44^{\prime} 43.12^{\prime \prime} \mathrm{N}$ & $73^{\circ} 25^{\prime} 52.61 " \mathrm{E}$ \\
\hline EC-22 & Khaji wala, Multan, Punjab, Pakistan & $30^{\circ} 88^{\prime} 32.90 " \mathrm{~N}$ & $71^{\circ} 22^{\prime} 53.94 " \mathrm{E}$ \\
\hline EC-23 & Mouza Talib Chiniot, Punjab, Pakistan & $31^{\circ} 41^{\prime} 18.14^{\prime \prime} \mathrm{N}$ & $73^{\circ} 1^{\prime} 16.67^{\prime \prime} \mathrm{E}$ \\
\hline EC-24 & Chak 169 P, Sadiqabad, Punjab, Pakistan & $28^{\circ} 16^{\prime} 48.63^{\prime \prime} \mathrm{N}$ & $70^{\circ} 8^{\prime} 54.39 " \mathrm{E}$ \\
\hline EC-25 & Tauheedabad, Chiniot, Punjab, Pakistan & $31^{\circ} 43^{\prime} 37.38^{\prime \prime} \mathrm{N}$ & $72^{\circ} 59^{\prime} 43.84^{\prime \prime} \mathrm{E}$ \\
\hline
\end{tabular}

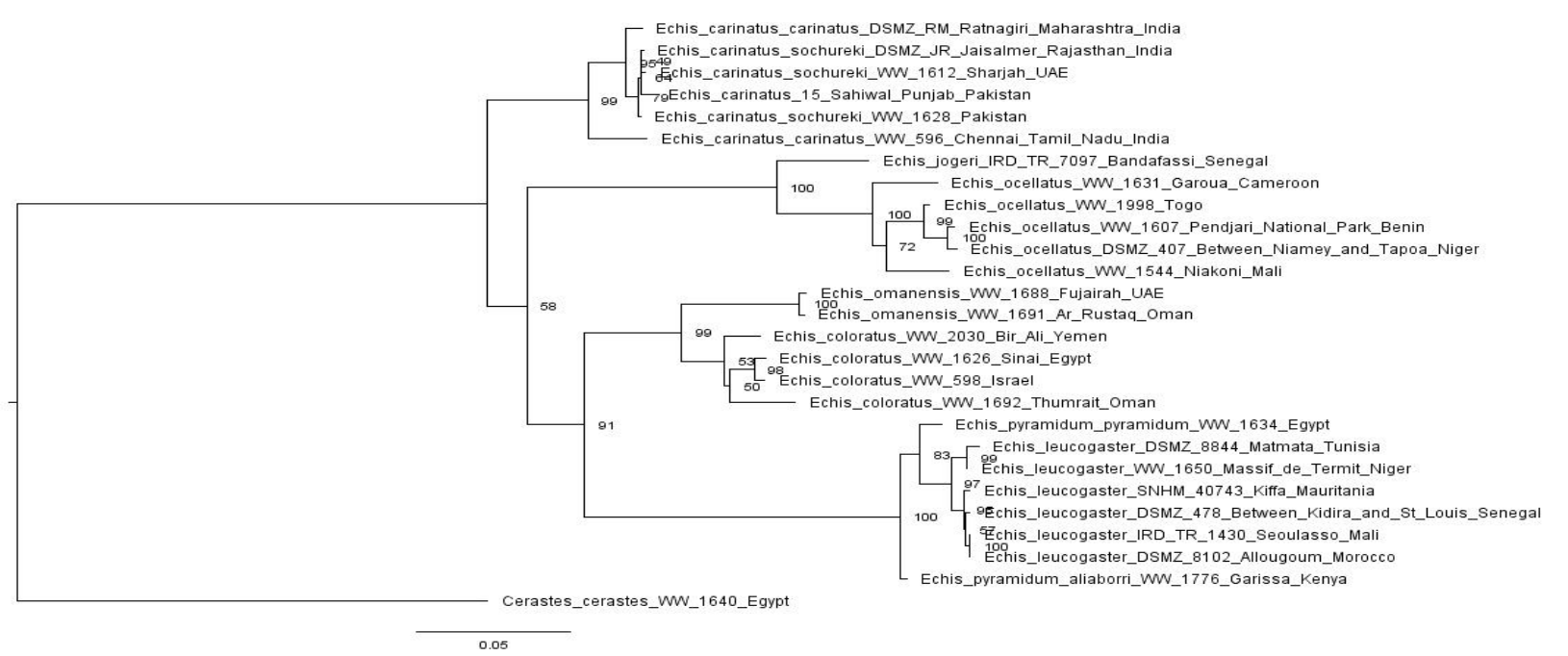

Fig. 2. Maximum likelihood (ML) phylogeny for Saw-scaled Viper (Echis carinaus sochureki). 


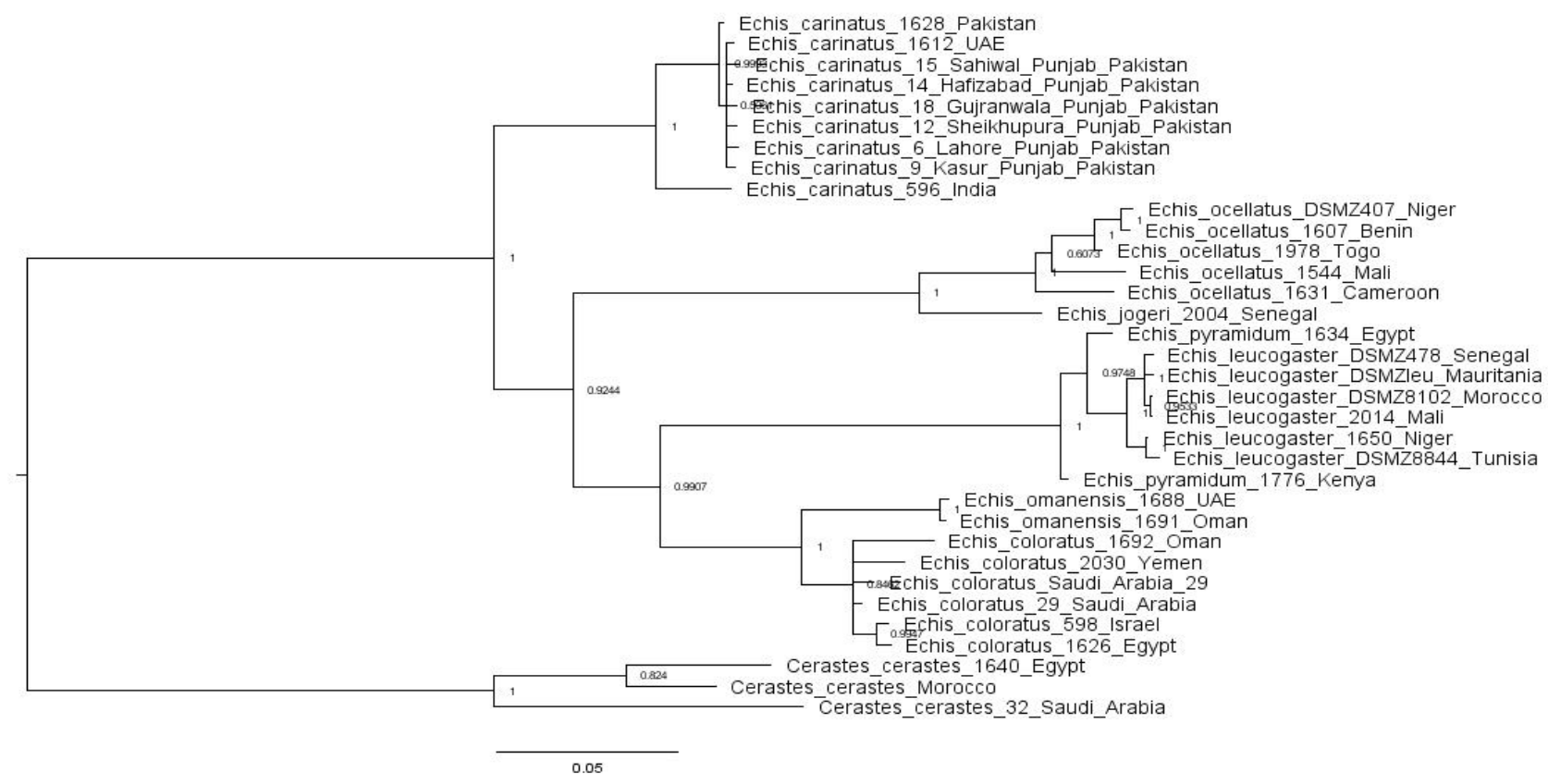

Fig. 3. Bayesian Phylogeny for Saw-scaled Viper (Echis carinatus sochureki).

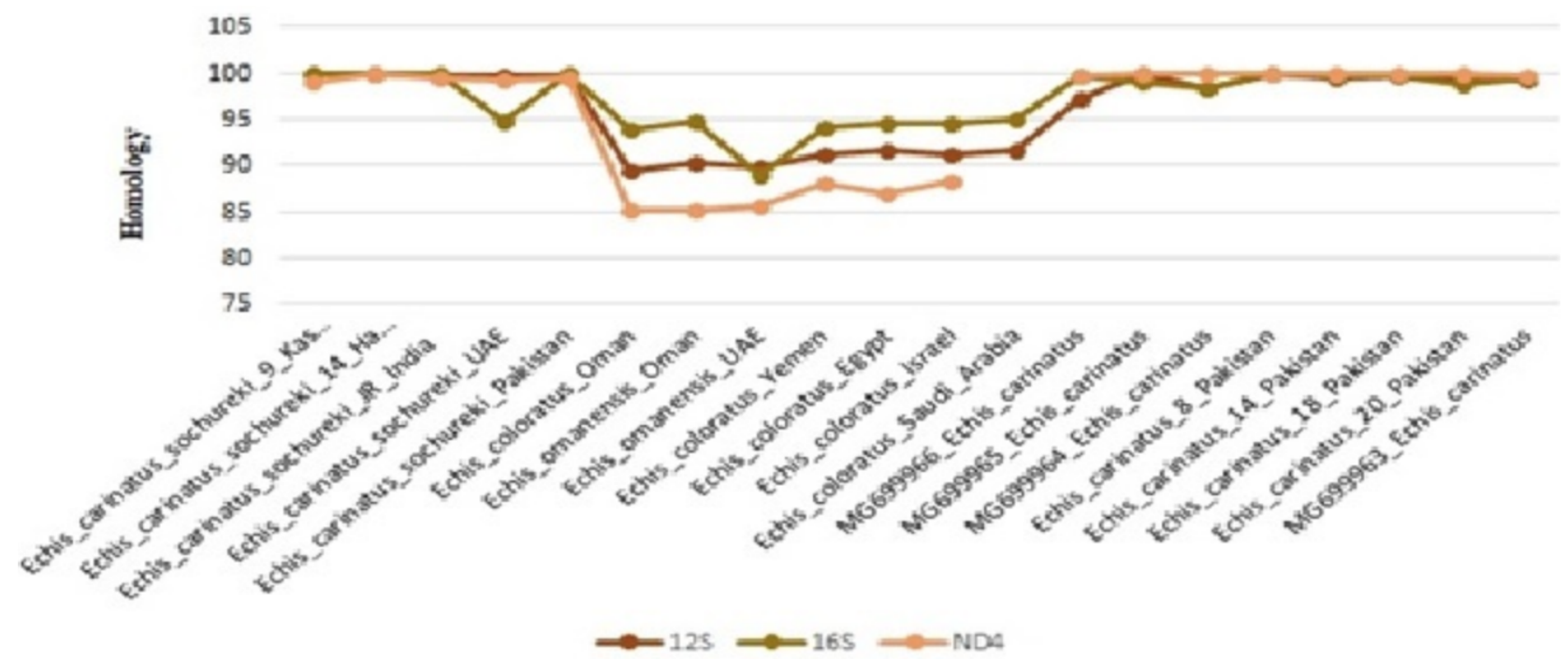

Fig. 4. Mitochondrial (ND4, 12S rRNA, 16S rRNA) gene-based homology of saw-scaled Viper (Echis carinatus).

showed almost similar topologies with best likelihood score $(\mathrm{InL}=-4498.85875)$ and $(\mathrm{LnL}=-6143.527)$. All Echis were divided into four distinct clades. These clades were Echis carinatus, E. ocellatus, E. pyramidum and E. coloratus. Although inter-relationship among the four clades was not found to be very well resolved. While Echis pyramidum and Echis coloratus groups showed well supported sister group relationship through (ML BS=91 and $\mathrm{BI} P \mathrm{P}=>98)$. On the other hand, both E. pyramidum and $E$. coloratus did not show well supported relationship with Echis carinatus and Echis ocellatus. Barlow et al. (2009) used mitochondrial and nuclear genes finding the same four clades of Echis with the same interrelationship among them. They inferred Bayesian phylogenies that showed Echis carinatus as sister to all other three Echis clades using cytochrome b, ND4, 12S rRNA, 16S rRNA and RAG-1. Using only one representative of all four Echis species they found highly supportive posterior probability 
value for monophyly of E. coloratus, E. pyramidum and E. ocellatus. Echis coloratus and E. pyramidum showed strong support for ( $\mathrm{ML} \mathrm{BS}=91, \mathrm{BI} \mathrm{PP}=0.98$ ) sister group relationship among them (Barlow et al., 2009). Furthermore, both the groups (coloratus and pyramidum) showed low support values for sister relationship with Echis ocellatus (ML BS=58, $\mathrm{BI} \mathrm{PP}=0.5966)$.

Table II. Polymorphism in mitochondrial genes of sawscaled viper (Echis carinatus sochureki).

\begin{tabular}{llll}
\hline Parameters & ND4 & 12S rRNA & 16S rRNA \\
\hline Total number of sites & 507 & 343 & 483 \\
Variable number of sites & 121 & 98 & 63 \\
Number of mutations & 159 & 131 & 79 \\
Singleton variable sites & 30 & 30 & 23 \\
Parsimony informative sites & 91 & 68 & 40 \\
Segregating sites & 82 & 00 & 00 \\
Number of haplotypes & 26 & 22 & 21 \\
Haplotype diversity & 0.764 & 0.767 & 0.727 \\
Nucleotide diversity & 0.09451 & 0.06942 & 0.04215 \\
\hline
\end{tabular}

\section{DISCUSSION}

Wild animals in Pakistan have always been ignored despite of being a very important part and asset of any ecosystem (Zafar et al., 2020). Saw-scaled vipers are found in a very large area from West Africa to India, including most of the Middle East countries. Their systematics and taxonomy has been a discussion for decades. In 1963, Klemmer recognized only two species: Echis carinatus in most of the range and E. coloratus in Arabia. Joger (1984, 1987) added E. pyramidum for southwestern Arabia. Cherlin (1990) described many new species and subspecies and increased the total number of Echis species significantly. A new species within the E. coloratus group was described by Babocsay (2004). Pook et al. (2009) using molecular genetic methods, have now clarified the complicated situation. Based on their results and additional data, they recognized the following six species in the near and Middle East. Echis carinatus group (Asian group): E. (carinatus) sochureki (Oman, UAE, Iran, Central Asia, Afghanistan, Pakistan), Echis coloratus group (Arabian group): E. coloratus (Egypt, Arabian Peninsula) E. omanensis (Oman, UAE) Echis pyramidum group (one of two African groups): E. pyramidum (Egypt, Sudan, East Africa) E. khosatzkii (western Oman, Yemen) E. sp. (cf. borkini) (Yemen, SW Saudi Arabia). E. borkini was originally described as a subspecies of the East African $E$. varia by Cherlin (1990).
As Echis bites frequently cause death and successful bite treatment depends on choosing a species-specific antivenom (if available), it is of great importance to know which species of Echis occur in which area. The present study inferred phylogenetic relationship of Sawscaled viper (Echis carinatus) with other species of genus Echis from GenBank database. Previously, there has been confusion in taxonomy of this genus, but this study gave an important phylogenetic key for interpretation of previous hypothesis from Pakistan. Mitochondrial genes were used in this study to infer the molecular phylogenetics of Saw scaled viper (E. carinatus) from different parts of Pakistan. Maximum likelihood and Bayesian inference phylogenies were constructed through RaxML and MrBayes softwares. Bayesian phylogeny showed good support $(\mathrm{PP}=1)$ but Maximum likelihood (ML) phylogeny of the Echis did not show any support on basal node. Cerastes cerastes (Egypt) was used as an out-group for all Echis species included. Pook et al. (2009) used cytochrome b, ND4, 12S rRNA and 16S rRNA genes to infer phylogenies of medically important and taxonomically unresolved genus Echis of vipers. Maximum likelihood and Bayesian phylogenies divided all Echis into four distinct groups i.e., Echis carinatus, E. ocellatus, E. pyramidum and E. coloratus group.

Barlow et al. (2009) used mitochondrial and nuclear genes finding the same four clades of Echis with the same interrelationship among them. They inferred Bayesian phylogenies that showed Echis carinatus as sister to all other three Echis clades using Cytochrome b, ND4, 12S rRNA, 16S rRNA, and RAG-1. The present study also used mitochondrial genes and found showed good support for sister group relationship of Echis carinatus with other three Echis groups in phylogenetic analyses. Saw-scaled viper (Echis carinatus) from Pakistan and UAE was similar to northern Indian parts and stated as different subspecies (Echis carinatus sochureki) from south Indian saw-scaled viper (Echis carinatus carinatus).

The present study also agrees with Rhadi et al. (2016) who used two mitochondrial genes (16S rRNA and Cytochrome b) for measuring phylogenetic affinities of Iraqi population of saw-scaled viper of genus Echis. They used 1,105 bp for inferring Maximum likelihood and Bayesian inferred topologies with similar pattern as in our study. Saw-scaled viper (Echis carinatus) from Pakistan and UAE were found to be distantly related to that of Iraq and India.

Similarly, Arnold et al. (2009) inferred phylogenetic somewhat similar relationship of Echis through mitochondrial DNA sequences using 1,117bp of two genes. Genus Echis was divided into four distinct clades through Maximum likelihood (ML), Maximum parsimony 
(MP) and Bayesian inference (BI) analyses. According to Arnold et al. (2009), Echis carinatus originated from Oman and Southern Iran and then dispersed to east and west of India and Iraq respectively.

On the other hand, Pook et al. (2009) suggested the origin from India and dispersal to north and west. Echis carinatus used in this study and those from NCBI database were divided into different groups. One group was from South India (Chennai Tamil Nadu), other one from Eastern and western India. Both of these groups included two haplotypes i.e., Echis carinatus carinatus (Maharashtra India) and Echis carinatus sochureki from Pakistan, UAE and Northern India (Rajasthan). Echis carinatus carinatus have also been found in southern Indian part Tamil Nadu.

Pook et al. (2009) found the same division of Echis carinatus as in our study. Their haplotypes included E. c. carinatus from India and Echis carinatus sochureki from Pakistan, Northeastern Arabian Peninsula. The haplotypes from northern part of range (Arabia, Pakistan, Central Asia and Northwestern India made a tightly packed cluster without having any clear phylogeographic structure showing recent divergence and dispersal. The basal sister groups have been shown to be originated from Maharashtra (Western India) and Tamil Nadu (Southern India).

The Echis carinatus group is the clade containing with minimum divergence between the populations. Cherlin identified three species i.e., E. multisquamatus (Central Asia, Iran), E. carinatus (southern India, Sri Lanka), E. sochureki (northern India to Pakistan), and Auffenberg and Rehman (1991) found clinal variation across the range of the group and considered all as subspecies of $E$. carinatus.

\section{CONCLUSION}

To infer more resolution in phylogenetic relationship and correct identification, more morphological and genetic studies are the required with diverse and increased number of samples from Indian subcontinent. This study is the first attempt to characterize, infer and molecular phylogenetics and genetic biodiversity in saw-scaled viper from Pakistan and will guide for further morphological and genetic studies about this genus and species which will ultimately help in designing the new local antivenom for snake bites in Pakistan as antivenom against snake bites is not as efficient as it is in India.

\section{Statement of conflict of interest}

The author(s) declare(s) that there is no conflict of interests regarding the publication of this article.

\section{REFERENCES}

Arevalo, E., Davis, S.K. and Sites, J.W. Jr., 1994. Mitochondrial DNA sequence divergence and phylogenetic relationships among eight chromosome races of the Sceloporus grammicus complex (Phrynosomatidae) in central Mexico. System Biol., 43: 387-418. https://doi.org/10.1093/ sysbio/43.3.387

Arnold, E.N., 1980. The reptiles and amphibians of Dhofar, Southern Arabia. J Oman Stud. Special Report, 2: 273-332.

Arnold, E.N., Robinson, M.D. and Carranza, S., 2009. A preliminary analysis of phylogenetic relationships and biogeography of the dangerously venomous Carpet Vipers, Echis (Squamata, Serpentes, Viperidae) based on mitochondrial DNA sequences. Amphibia-Reptilia, 30: 273-282. https:// doi.org/10.1163/156853809788201090

Auffenberg, W. and Rehman, H., 1991. Studies on Pakistan reptiles. Part 1. The genus Echis (Viperidae). Bull. Florida Mus. Nat. Hist. Biol. Sci., 35: 263-314.

Babocsay, G., 2004. A new species of saw-scaled viper of the Echis coloratus complex (Ophidia: Viperidae) from Oman, Eastern Arabia. Systemat. Biodiv., 1: 503-514. https://doi.org/10.1017/ S1477200003001294

Barlow, A., Pook, C.E., Harrison, R.A. and Wuster, W., 2009. Co-evolution of diet and prey-specific venom activity supports the role of selection in snake venom evolution. Proc. R. Soc. B., 276: 2443-2449. https://doi.org/10.1098/rspb.2009.0048

Castresana, J., 2000. Selection of conserved blocks from multiple alignments for their use in phylogenetic analysis. Mol. Biol. Evolut., 17: 540-552. https:// doi.org/10.1093/oxfordjournals.molbev.a026334

Cherlin, V., 1990. Taxonomic revision of the snake genus Echis (viperidae) II. An analysis of taxonomy and description of new forms. Proc. Zool. Inst. Leningrad. 193-223.

Hillis, D.M. and Bull, J.J., 1993. An empirical test of bootstrapping as a method for assessing confidence in phylogenetic analysis. System. Biol., 42: 182192. https://doi.org/10.1093/sysbio/42.2.182

Joger, U., 1984. The venomous snakes of the Near and Middle East. L. Reichert.

Joger, U., 1987. An interpretation of reptile zoogeography in Arabia, with special reference to Arabian herpetofaunal relations with Africa. Proc. Symp. Fauna Zoogeogr. Middle East, Mainz. pp. 211-251. 
Joger, U., Courage, K., 1999. Are Palaearctic 'rattlesnakes' (Echis and Cerastes) monophyletic? Kaup, 8: 65-81.

Kasturiratne, A., Wickremasinghe, A.R., de Silva, N., Gunawardena, N.K., Pathmeswaran, A., Premaratna, R., Savioli, L., Lalloo, D.G. and de Silva, H.J., 2008. The global burden of snakebite: a literature analysis and modelling based on regional estimates of envenoming and deaths. PLOS Med., 5: p.e218. https://doi.org/10.1371/journal. pmed.0050218

Klemmer, K., 1963. Liste der rezenten Giftschlangen: Elapidae, Hydropheidae, Viperidae und Crotalidae: NG Elwert, Marburg/Lahn.

Knight, A. and Mindell, D.P., 1993. Substitution bias, weighting of DNA sequence evolution, and the phylogenetic position of Fea's viper. System. Biol., 42: 18-31. https://doi.org/10.1093/sysbio/42.1.18

Lanfear, R., Calcott, B., Ho, S.Y.W., Guindon, S., 2012. PartitionFinder: Combined selection of partitioning schemes and substitution models for phylogenetic analyses. Mol. Biol. Evolut. 29: 1695-1701. https:// doi.org/10.1093/molbev/mss020

Larkin, M.A., Blackshields. G., Brown, N., Chenna, R., McGettigan, P.A., McWilliam, H., Valentin, F., Wallace, I.M., Wilm, A. and Lopez, R., 2007. Clustal $W$ and Clustal $X$ version 2.0. Bioinformatics, 23: 2947-2948. https://doi.org/10.1093/bioinformatics/ btm 404

Lawson, R., Slowinski, J.B. and Burbrink, F.T., 2004. A molecular approach to discerning the phylogenetic placement of the enigmatic snake Xenophidion schaeferi among the Alethinophidia. J. Zool., 263: 285-294. https://doi.org/10.1017/ S0952836904005278

Lee, M.S. and Scanlon, J.D., 2002a. Snake phylogeny based on osteology, soft anatomy and ecology. Biolog Rev., 77: 333-401. https://doi.org/10.1017/ S1464793102005924

Lenk, P., Kalayabina, S., Wink, M. and Joger, U., 2001. Evolutionary relationships among the true vipers (Reptilia: Viperidae) inferred from mitochondrial DNA sequences. Mol. Phylogen. Evolut., 19: 94104. https://doi.org/10.1006/mpev.2001.0912

Librado, P. and Rozas, J., 2009. DnaSP v5: A software for comprehensive analysis of DNA polymorphism data. Bioinformatics, 25:1451-1452. https://doi. org/10.1093/bioinformatics/btp187

Iliyas, M., 1997. Community medicine. 4th Edition. Time Reader, Karachi, pp. 544-545.

Macey, J.R., Schulte, J.A., Larson, A., Ananjeva, N.B, Wang, Y., Pethiyagoda, R., Rastegar-Pouyani, N.,
Papenfuss, T.J., 2000. Evaluating trans-Tethys migration: an example using acrodont lizard phylogenetics. System. Biol., 49: 233-256. https:// doi.org/10.1093/sysbio/49.2.233

Miller, M.A., Pfeiffer, W. and Schwartz, T., 2010. Creating the CIPRES Science Gateway for inference of large phylogenetic trees. Gateway Computing Environments Workshop (GCE)., pp. 1-8. https://doi.org/10.1109/GCE.2010.5676129

Mulcahy, D.G., Beckstead, T.H. and Sites, Jr. J.W., 2011. Molecular systematics of the Leptodeirini (Colubroidea: Dipsadidae) revisited: Speciestree analyses and multi-locus data. Committee on Publication Ethics, pp. 407-417. https://doi. org/10.1643/CH-10-058

Pook, C.E., Joger, U., Stumpel, N. and Wuster, W., 2009. When continents collide: phylogeny, historical biogeography and systematics of the medically important viper genus Echis (Squamata: Serpentes: Viperidae). Mol. Phylogenet. Evolut., 53: 792-807. https://doi.org/10.1016/j.ympev.2009.08.002

Rambaut, A., 2007. Fig tree, a graphical viewer of phylogenetic trees. Version 1.4.

Rambaut, A. and Drummond, A., 2009. Tracer v1.5. Available from: http:// tree.bio.ed.ac.uk/software/ tracer/.

Rhadi, F.A., Rastegar-Pouyani, E., Rastegar-Pouyani, N., Mohammed, R.G. and Yousef-khani, S.S.H., 2016. Phylogenetic affinities of the Iraqi populations of Saw-scaled vipers of the genus Echis (Serpentes: Viperidae), revealed by sequences of mtDNA genes. Zool. Middle East., 62: 299-305. https://doi. org/10.1080/09397140.2016.1257402

Ronquist, F. and Huelsenbeck, J.P., 2012. MrBayes 3: Bayesian phylogenetic inference under mixed models. Bioinformatics, 19: 1572-1574. https://doi. org/10.1093/bioinformatics/btg180

Sambrook, J., Russel, D.W., 2001. Rapid isolation of yeast DNA. In: Molecular cloning, a laboratory manual (eds. J. Sambrook and D.W. Russel). Cold Spring Harbor Laboratory, New York., pp. 631-632.

Simon, C., Frati, F., Beckenbach, A., Crespi, B., Liu, H., Flook, P., 1994. Evolution, weighting, and phylogenetic utility of mitochondrial gene sequences and a compilation of conserved polymerase chain reaction primers. Annls entomol. Soc. Am., 87: 651-701. https://doi.org/10.1093/ aesa/87.6.651

Stamatakis, A., 2014. RAxML version 8: A tool for phylogenetic analysis and post-analysis of large phylogenies. Bioinformatics, 30: 1312-1313. https://doi.org/10.1093/bioinformatics/btu033 
Tamura, K., Stecher, G., Peterson, D., Filipski, A. and Kumar, S., 2013. MEGA6: Molecular Evolutionary Genetics Analysis Version 6.0. Mol. Biol. Evolut., 30: 2725-2729. https://doi.org/10.1093/molbev/ mst197

Tchernov, E., Rieppel, O., Zaher, H., Polcyn, M.J. and Jacobs, L.L., 2000. A fossil snake with limbs. Science, 287: 2010-2012. https://doi.org/10.1126/ science. 287.5460 .2010

Vaidya, G., Lohman, D.J. and Meier, R., 2011. SequenceMatrix: Concatenation software for the fast assembly of multi-gene datasets with character set and codon information. Cladist, 27: 171-180. https://doi.org/10.1111/j.1096-0031.2010.00329.x

Vences, M., Thomas, M., Meijden, A., Chiari, Y. and Vieites, D.R., 2005. Comparative performance of the 16S rRNA gene in DNA barcoding of amphibians. Front. Zool., 2: 5. https://doi.org/10.1186/17429994-2-5
Vidal, N. and Hedges, S.B., 2002a. Higher-level relationships of caenophidian snakes inferred from four nuclear and mitochondrial genes. Compt. Rend. Biol., 325: 987-995. https://doi.org/10.1016/S16310691(02)01509-3

Vidal, N. and Hedges, S.B., 2004. Molecular evidence for a terrestrial origin of snakes, Proc. Roy. Soc. Lond. B., 271: S226-S229. https://doi.org/10.1098/ rsbl.2003.0151

Wuster, W., Peppin, L., Pook, C.E. and Walker, D.E., 2008. A nesting of vipers: Phylogeny and historical biogeography of the Viperidae (Squamata: Serpentes). Mol. Phylogenet. Evolut., 49: 445-459. https://doi.org/10.1016/j.ympev.2008.08.019

Zafar, J., Nadeem, A., Javed, M , Fatima, F., Shehzad, W., Abbas, G., Iqbal,R.Z. and Ali, M.M., 2020. Assessment of mitochondrial ATPase $8 / 6$ genes based genetic diversity in Sindh Ibex (Capra aegagrus Blythi). Pakistan J. Zool., 52: $441-446$. 